\title{
Crosstalk between p38 MAPK and caspase-9 regulates mitochondria-mediated apoptosis induced by tetra- $\alpha$-(4-carboxyphenoxy) phthalocyanine zinc photodynamic therapy in LoVo cells
}

\author{
YU WANG ${ }^{1}$, CHUNHUI XIA ${ }^{1}$, ZHIQIANG LUN ${ }^{1}$, YANXIN LV ${ }^{1}$, WEI CHEN ${ }^{2}$ and TAO LI ${ }^{1}$ \\ ${ }^{1}$ Department of Basic Medicine, Qiqihar Medical University, Qiqihar, Heilongjiang 161006; ${ }^{2}$ College of Chemistry \\ and Chemical Engineering, Qiqihar University, Qiqihar, Heilongjiang 161006, P.R. China
}

Received May 19, 2017; Accepted October 11, 2017

DOI: $10.3892 / o r .2017 .6071$

\begin{abstract}
Photodynamic therapy (PDT) is considered to be an advancing antitumor technology. PDT using hydrophilic/lipophilic tetra- $\alpha$-(4-carboxyphenoxy) phthalocyanine zinc (T $\alpha \mathrm{PcZn}$-PDT) has exhibited antitumor activity in Bel-7402 hepatocellular cancer cells. However, the manner in which p38 MAPK and caspase-9 are involved in the regulation of mitochondria-mediated apoptosis in the TaPcZn-PDT-treated LoVo human colon carcinoma cells remains unclear. Therefore, in the present study, a siRNA targeting $p 38 M A P K$ (siRNA-p38 MAPK) and the caspase-9 specific inhibitor z-LEHD-fmk were used to examine the crosstalk between p38 MAPK and caspase-9 during mitochondria-mediated apoptosis in the TaPcZn-PDT-treated LoVo cells. The findings revealed that the TaPcZn-PDT treatment of LoVo cells resulted in the induction of apoptosis, the formation of p38 MAPK/caspase- 9 complexes, the activation of p38 MAPK, caspase- 9 , caspase- 3 and Bid, the downregulation of $\mathrm{Bcl}-2$, the reduction of mitochondrial membrane potential $(\Delta \Psi \mathrm{m})$, the upregulation of Bax and the release of apoptosis-inducing factor (AIF) and cytochrome $c$ (Cyto $c$ ). By contrast, siRNA-p38 MAPK or z-LEHD-fmk both attenuated the effects of TaPcZn-PDT in the LoVo cells. Furthermore, the results revealed that siRNA-p38 MAPK had more significant inhibitory effects on apoptosis and mitochondria compared with the effects of z-LEHD-fmk in T $\alpha$ PcZn-PDT-treated LoVo cells. These findings indicated that p38 MAPK plays the major regulatory role in the crosstalk between p38 MAPK and caspase-9 and that
\end{abstract}

Correspondence to: Professor Tao $\mathrm{Li}$, Department of Basic Medicine, Qiqihar Medical University, 333 Bukuibei'er Road, Jianhua, Qiqihar, Heilongjiang 161006, P.R. China

E-mail: 1itao888@qmu.edu.cn

Key words: tetra- $\alpha$-(4-carboxyphenoxy) phthalocyanine zinc, photodynamic therapy, p38 MAPK, caspase-9, signaling crosstalk, apoptosis, mitochondria direct interaction between p38 MAPK and caspase- 9 may regulate mitochondria-mediated apoptosis in the TaPcZnPDT-treated LoVo cells.

\section{Introduction}

Photodynamic therapy (PDT) is an advancing medical technology that uses photosensitizing drugs. When the photosensitizing agent is exposed to an appropriate wavelength of light, reactive oxygen species (ROS) are produced which may kill nearby tumor cells (1-5). Unlike conventional therapeutics, PDT can selectively destroy tumor tissues, as well as control and reduce the degree of damage to normal tissues. Photosensitizers play a key role in PDT. Currently, only a few porphyrin photosensitizers (e.g. 5-aminolevulinic acid, temoporfin) are approved for the treatment of cancer in humans. Although these photosensitizers have demonstrated a wide spectrum of antitumor effects, they have various deficiencies. Thus, the development of better photosensitizing candidate drugs is required. Phthalocyanines, which have desirable electronic absorption and photophysical properties, are some of the most promising potential photosensitizer candidates. Phthalocyanines have a hydrophilic/lipophilic structure. The hydrophilic group enhances the transport of the drug in the body and the lipophilic group enhances the uptake of the drug by the cancer cells. Recently, accumulating evidence revealed that PDT using hydrophilic/lipophilic phthalocyanines achieved highly selective antitumor effects (6-9).

Mitochondria play a pivotal role in the initiation and amplification of most apoptotic pathways. When mitochondria are stimulated by apoptotic signals, the mitochondrial membrane-permeability is increased, leading to the release of cytochrome $c$ (Cyto $c$ ) and the apoptosis-inducing factor (AIF) into the cytoplasm resulting in mitochondria-mediated apoptosis (10-16). Additionally, mitochondria are regulated by the Bcl-2 family, the caspase family and the mitogen-activated protein kinase (MAPK) proteins (17-22). The Bcl-2 family of proteins are a group of evolutionarily related apoptosis-regulation proteins that regulate mitochondrial membrane-permeabilization; Bax and Bid are pro-apoptotic proteins and $\mathrm{Bcl}-2$ is an anti-apoptotic protein. Recent studies 
demonstrated that the mitochondrial transmembrane potential of cancer cells is altered by phthalocyanine-PDT $(23,24)$.

Caspase-9, a member of the caspase family of proteases, is the main executor of apoptosis signaling. Once activated, initiator caspase- 9 cleaves effector caspase-3, which subsequently, induces the morphological and functional changes associated with apoptosis. Accumulating evidence has demonstrated that caspase- 9 and caspase- 3 play crucial regulatory roles in the phthalocyanine-PDT-induced apoptosis of cancer cells $(23,24)$. In addition, accumulating evidence has revealed that caspase- 9 is involved in the regulation of cell autophagy and is an important determinant of the balance between cell apoptosis and autophagy $(25,26)$.

MAPKs, a family of protein serine/threonine kinases, include extracellular signal-regulated kinase (ERK), c-Jun NH2-terminal protein kinase (JNK) and p38 kinase. MAPKs are activated in response to cellular stimuli and are involved in the regulation of cellular processes such as proliferation, apoptosis and autophagy $(27,28)$. Among the MAPKs subfamily, p38 MAPK-activation is mainly implicated in stress stimuli (oxidative stress, ultraviolet irradiation, chemotherapeutics, hyperthermia)-induced apoptosis $(29,30)$. Accumulating evidence has indicated that p38 MAPK activation plays a crucial regulatory role in phthalocyanine-PDT-induced apoptosis of cancer cells $(8,31,32)$.

Our previous study demonstrated that p38 MAPK and caspase- 8 regulated the apoptosis of Bel-7402 human hepatocellular carcinoma cells induced by hydrophilic/lipophilic tetra- $\alpha$-(4-carboxyphenoxy) phthalocyanine zinc (T $\alpha$ PcZn)-PDT $(6,8)$. However, the manner through which p38 MAPK or caspase-9 regulated mitochondria-mediated apoptosis in LoVo human colon carcinoma cells treated with TaPcZn-PDT is not clear. In the present study, a siRNA targeting $p 38 M A P K$ mRNA (siRNA-p38 MAPK) and the caspase-9-specific inhibitor z-LEHD-fmk were used to investigate the crosstalk between p38 MAPK and caspase-9 as part of apoptosis in the TaPcZn-PDT-treated LoVo cells. The findings indicated that p38 MAPK in a crosstalk between p38 MAPK and caspase-9 may play an important regulatory role and that direct crosstalk between p38 MAPK and caspase-9 may regulate mitochondria-mediated apoptosis in the T $\alpha$ PcZn-PDT-treated LoVo cells.

\section{Materials and methods}

Antibodies and reagents. Dulbecco's modified Eagle's medium (DMEM), opti-MEM, Silencer Select siRNA-p38 MAPK, negative control siRNA, GAPDH positive control siRNA and lipofectamine RNAiMAX were all purchased from Thermo Fisher Scientific (Carlsbad, CA, USA). Fetal bovine serum (FBS) was purchased from PAA Laboratories (Cölbe, Germany). Diethyl sulfoxide (DMSO) was purchased from Sigma-Aldrich (St. Louis, MO, USA). Anti-p38 MAPK, antiphosphorylated (p)-p38 MAPK, anti-Bcl-2, anti-Bax, anti-AIF, anti-Cyto $c$, anti-Bid, anti-caspase- 9 and anti-caspase- 3 antibodies were all purchased from Cell Signaling Technology (Danvers, MA, USA). The anti- $\beta$-actin antibody was obtained from Santa Cruz Biotechnology (Santa Cruz, CA, USA). Z-LEHD-fmk was obtained from Merck Chemicals GmbH (Darmstadt, Germany). The Annexin V-FLUOS staining kit was purchased from Roche (Basel, Switzerland). The reverse transcription-polymerase chain reaction (RT-PCR) kit was obtained from Takara (Dalian, China). The 5,5',6,6'-tetrachloro-1,1',3,3'-tetraethylbenzimidazolylcarbocyanine iodide (JC-1) staining kit was purchased from Genmed Scientifics (Wilmington, DE, USA). Catch and Release v2.0 kit was purchased from Millipore (Billerica, MA, USA). TaPcZn was synthesized as described in our previous study (33). The T $\alpha$ PcZn stock solution was prepared in DMSO and stored in the dark at $4^{\circ} \mathrm{C}$. When used, the stock solution was appropriately diluted to obtain the desired concentration with a final DMSO concentration of $0.1 \%$. All other chemicals and reagents were of analytical grade.

Cell culture and treatment. The LoVo cells were obtained from Harbin Medical University (Harbin, China) and cultured in DMEM supplemented with $10 \%$ FBS, $100 \mathrm{U} / \mathrm{ml}$ penicillin and $100 \mathrm{mg} / \mathrm{l}$ streptomycin in a humidified atmosphere of $5 \% \mathrm{CO}_{2}$ at $37^{\circ} \mathrm{C}$. The LoVo cells were incubated for $48 \mathrm{~h}$. After treatment with the T $\alpha \mathrm{PcZn}$ stock solution for $2.5 \mathrm{~h}$ at $37^{\circ} \mathrm{C}$ in the presence or absence of siRNA-p38 MAPK or z-LEHD-fmk, the cells were irradiated with an SS-B instrument (Wuxi Holyglow Physiotherapy Instrument Co., Ltd., Jiangsu, China) that emitted red light within a wavelength of $600-700 \mathrm{~nm}$. The light dose was $\sim 53.7 \mathrm{~J} / \mathrm{cm}^{2}$. The cells were harvested after $3 \mathrm{~h}$. The control cells were exposed to red light irradiation $\left(53.7 \mathrm{~J} / \mathrm{cm}^{2}\right)$.

siRNA transfection. The cells were transfected with siRNAs using lipofectamine RNAiMAX reagent according to the manufacturer's instructions and assayed $48 \mathrm{~h}$ after transfection. Control non-targeting siRNA, GAPDH positive control siRNA and siRNA against $p 38 M A P K$ (12.5 nM) were all obtained from Thermo Fisher Scientific. The target sequence of the $p 38 M A P K$ siRNA was 5'-GAAGCUCUCCAGACCAUUUTT-3'. The silencing efficiency was validated by RT-PCR and immunoblot analysis.

Semi-quantitative RT-PCR. Total cellular RNA was extracted and the cDNA was synthesized using standard protocols. PCR primers specific for p38 MAPK (forward, 5'-GACAATCTGGGAGGTGCC-3' and reverse, 5'-GACCCAGTCCAAAATCCA-3') and GAPDH (forward, 5'-GAAGGTGAAGGTCGGAGTC-3' and reverse, 5'-GAAGATGGTGATGGGATTTC-3') were applied. RT was performed on $1 \mu \mathrm{g}$ total RNA with a reaction mixture containing $10 \mu \mathrm{l}$ denatured RNA in a 96-well thermal cycler (Bio-Rad Laboratories, Inc., Hercules, CA, USA), $1 \mu 1$ 10X RT buffer, $2 \mu \mathrm{l}$ (12.5 mM) $\mathrm{MgCl}_{2}, 1 \mu \mathrm{l}$ dNTP mix, $0.5 \mu \mathrm{l}$ AMV reverse transcriptase, $0.5 \mu \mathrm{l}$ Oligo dT-adaptor primer, $0.25 \mu \mathrm{l}$ RNase inhibitor and $3.75 \mu \mathrm{l}$ distilled water. cDNA was synthesized by incubation at $30^{\circ} \mathrm{C}$ for $10 \mathrm{~min}$ and then $42^{\circ} \mathrm{C}$ for $30 \mathrm{~min}, 99^{\circ} \mathrm{C}$ for $5 \mathrm{~min}$ and $5^{\circ} \mathrm{C}$ for $5 \mathrm{~min}$. The PCR was performed on $5 \mu \mathrm{l}$ cDNA product, which was added to a $20-\mu 1$ PCR mixture comprised of $5 \mu$ l PCR Buffer, $0.125 \mu$ l Takara Ex Taq HS, $0.5 \mu \mathrm{l}$ forward and reverse primers and $14.375 \mu \mathrm{l}$ distilled water. The PCR reaction was carried out using one cycle at $94^{\circ} \mathrm{C}$ for $2 \mathrm{~min}$, followed by 35 cycles at $94^{\circ} \mathrm{C}$ for $30 \mathrm{sec}$, annealing at $59^{\circ} \mathrm{C}$ for $30 \mathrm{sec}$, polymerization at $72^{\circ} \mathrm{C}$ for $1 \mathrm{~min}$ and a final extension at $72^{\circ} \mathrm{C}$ for $10 \mathrm{~min}$. The RT-PCR 
products were separated by electrophoresis in $1.5 \%$ agarose gels and bands were visualized and quantified on a Molecular Imager ${ }^{\circledR}$ Gel Doc ${ }^{\mathrm{TM}}$ XR system with Image Lab $^{\mathrm{TM}}$ software v.4.1 (Bio-Rad Laboratories). The samples exhibiting 220 and 460 bp bands were considered positive. GAPDH was used as an internal control. Densitometric quantifications of the objective RNA levels were made relative to GAPDH. Quantitative data were presented as the mean \pm standard deviation (SD) from three independent experiments and were analyzed using an analysis of variance (ANOVA).

Annexin V-FLUOS/Propidium iodide (PI) double-staining analysis of apoptosis. Cell apoptosis was assayed using the Annexin V-FLUOS/PI apoptosis detection kit. The harvested LoVo cells were washed with ice-cold PBS and suspended in $500 \mu \mathrm{l}$ Annexin $\mathrm{V}$ binding buffer $\mathrm{A}$, after which $100 \mu \mathrm{l}$ aliquots were collected. Subsequently, $2.0 \mu 1$ Annexin V-FLUOS and $2.0 \mu \mathrm{l}$ PI were added and the mixture was incubated for $5 \mathrm{~min}$ in the dark at room temperature. After $5 \mathrm{~min}, 400 \mu \mathrm{l}$ binding buffer was added to the cells and $1 \times 10^{4}$ cells were analyzed on a FACScan flow cytometer (Becton Dickinson, Franklin Lakes, NJ, USA) using CellQuest software. The results are shown as dotplots. In each graph, the percentage of apoptotic cells is indicated in the right upper and lower quadrant; the $\mathrm{y}$-axis corresponds to the relative PI staining and the $\mathrm{x}$-axis corresponds to the log of the FLUOS signal.

$J C-1$ assay of the mitochondria membrane potential $\left(\Delta \Psi_{m}\right)$. The $\Delta \Psi \mathrm{m}$ was assayed by JC-1 assay using fluorescence microscopy and flow cytometry. For the fluorescence microscopic analysis, after being treated with TaPcZn-PDT in the absence or presence of siRNA-p38 MAPK or z-LEHD-fmk, the cells were incubated in fresh culture medium containing $2.5 \mu \mathrm{g} / \mathrm{ml} \mathrm{JC}-1$ for $20 \mathrm{~min}$ in the dark at $37^{\circ} \mathrm{C}$ and washed twice with PBS and then, assayed using an inverted fluorescence microscope (Chongqing Photoelectric Instruments Co. Ltd., Chongqing, China). For the flow cytometric analysis, after being treated with TaPcZn-PDT in the absence or presence of siRNA-p38 MAPK or z-LEHD-fmk, the cells were trypsinized and washed twice with PBS and then incubated in PBS containing $2.5 \mu \mathrm{g} / \mathrm{ml} \mathrm{JC}-1$ for $20 \mathrm{~min}$ in the dark at $37^{\circ} \mathrm{C}$. About $1 \times 10^{4}$ cells were analyzed on a FACScan flow cytometer (Becton Dickinson) using CellQuest software. The results observed by flow cytometry are demonstrated as dotplots. In each graph, the shift of fluorescence from red to green indicated the collapse of the $\Delta \Psi \mathrm{m}$.

Immunoblot assay. All immunoblots were performed using sodium dodecyl sulfate-polyacrylamide gel electrophoresis (SDS-PAGE) according to the manufacturer's instructions. To obtain total cellular protein, the LoVo cells were lysed in buffer containing $25 \mathrm{mM}$ 4-(2-hydroxyethyl)-1-piperazineethanesulfonic acid ( $\mathrm{pH} 7.5$ ), $0.3 \mathrm{M} \mathrm{NaCl}, 1.5 \mathrm{mM} \mathrm{MgCl}_{2}, 0.2 \mathrm{mM}$ ethylenediaminetetraacetic acid, 0.1\% Triton X-100, $20 \mathrm{mM}$ $\beta$-glycerophosphate, $0.5 \mathrm{mM}$ dithiothreitol, $1.0 \mathrm{mM}$ sodium orthovanadate, $0.1 \mathrm{mM}$ okadaic acid and $1.0 \mathrm{mM}$ phenylmethylsulfonyl fluoride. Equal amounts of protein lysate were run on $10 \%$ SDS-PAGE and electrophoretically transferred to polyvinylidene fluoride membranes. After blocking, the blots were incubated with specific primary antibodies (anti-p38 MAPK, anti-phos-p38 MAPK, anti-caspase-3, anti-caspase-9, anti-Bcl-2, anti-Bax and anti-Bid antibodies) overnight at $4^{\circ} \mathrm{C}$ and further incubated for $1 \mathrm{~h}$ with horseradish peroxidase-conjugated secondary antibodies. Bound antibodies were detected using an enhanced chemiluminescence (ECL) kit with Lumino Image analyzer (Founder Group, Beijing, China). The mitochondria and cytosolic fractions isolated from the cells were collected for immunoblot assay of Cyto $c$ and AIF, as previously described (34). The Cyto $c$ and AIF proteins were assayed using anti-Cyto $c$ and anti-AIF antibodies. All densitometric quantifications of the protein levels were made relative to $\beta$-actin and expressed in arbitrary units.

Immunoprecipitation/immunoblot assay. The cell lysates and the affinity ligands were incubated with the p38 MAPK antibody or caspase- 9 antibody in a spin-column at $4^{\circ} \mathrm{C}$ overnight. After washing the column three times with $1 \mathrm{X}$ washing buffer, the protein was eluted from the column in native form. The immunoprecipitates were separated by $10 \%$ SDS-PAGE. After being transferred, the membranes were immunoblotted with the p38 MAPK antibody or caspase- 9 antibody, washed with Tween-PBS and developed using the ECL system.

Localized surface plasmon resonance (LSPR) signal detection. A COOH sensor chip was loaded into the OpenSPR instrument (Nicoya Lifesciences, Kitchener, ON, Canada), running buffer (1X PBS, pH 7.4) was pumped and $200 \mu 1$ 1-(3-dimethylaminopropyl)-3-ethylcarbodiimide hydrochloride $(0.04 \mathrm{mg} / \mathrm{ml}) / \mathrm{N}$-hydroxysuccinimide $(0.06 \mathrm{mg} / \mathrm{ml})$ mixture in the activation buffer was injected into the instrument. Subsequently, after $5 \mathrm{~min}, 200 \mu \mathrm{l}$ anti-p38 MAPK antibody in PBS solution $(8.55 \mu \mathrm{g} / \mathrm{ml})$ was injected into the instrument. After $5 \mathrm{~min}$, a $200 \mu \mathrm{l}$ blocking solution was injected and then, after a further $5 \mathrm{~min}, 200 \mu \mathrm{l}$ of treatedproteins in PBS $(80 \mu \mathrm{g} / \mathrm{ml})$ and $200 \mu \mathrm{l}$ anti-caspase- 9 antibody PBS solution $(11.56 \mu \mathrm{g} / \mathrm{ml})$ were injected into the instrument to assess the interactions between p38 MAPK, caspase- 9 and total protein. The interactions were assayed by the resonance wavelength that was obtained by fitting the LSPR signals to the Lorentzian equation.

Statistical analysis. All data are presented as the mean \pm standard deviation (SD) and were analyzed using an analysis of variance (ANOVA). $\mathrm{P}<0.05$ was considered to indicate a statistically significant difference and $\mathrm{P}<0.01$ was considered to indicate a highly statistically significant difference in all cases. Statistical analyses were performed using SPSS version 18.0 (SPSS, Inc., Chicago, IL, USA).

\section{Results}

siRNA silencing of p38 MAPK. To analyze the effect of p38 MAPK silencing in the TaPcZn-PDT-treated LoVo cells, the cells were transfected with siRNA-p38 MAPK. The siRNA transfection rate was $\sim 90 \%$ (Fig. 1A and B). After the siRNA-p38 MAPK transfection, the expression levels of p38 MAPK mRNA and p38 MAPK protein in the LoVo cells decreased significantly (Fig. 1C-F), indicating that siRNA silenced the expression of $p 38$ MAPK. 
A
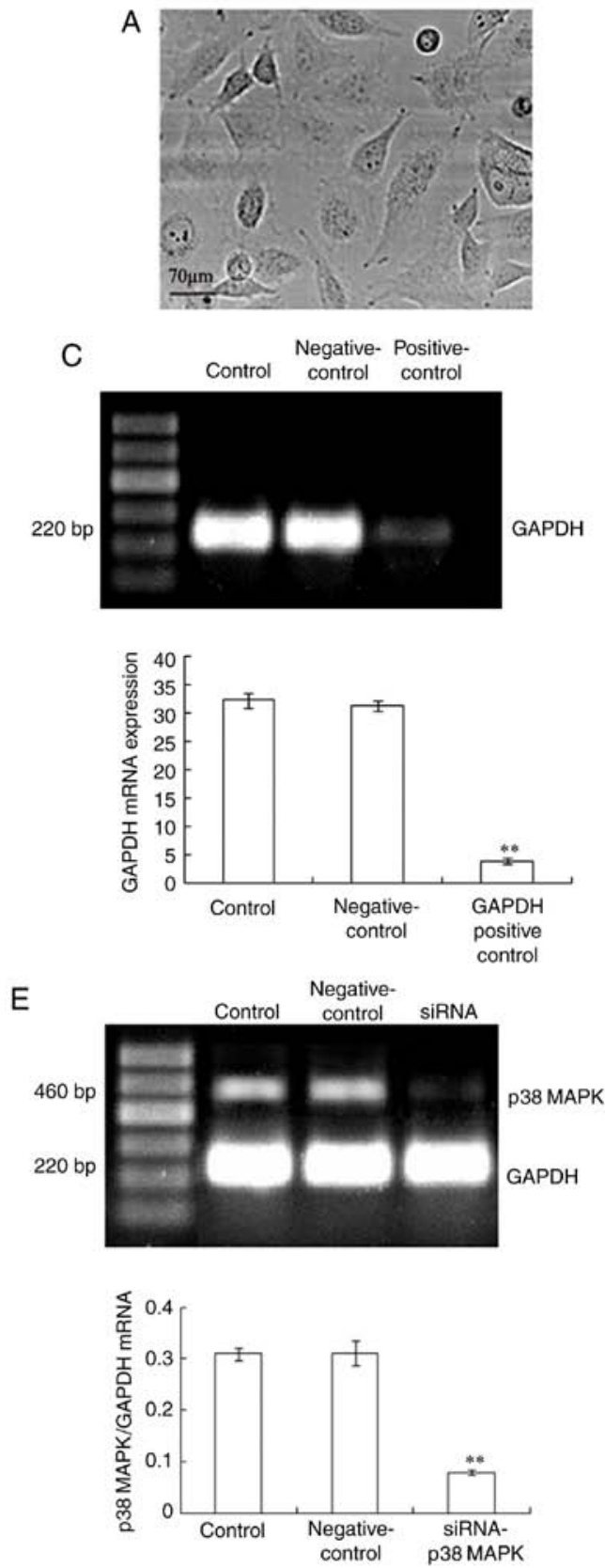
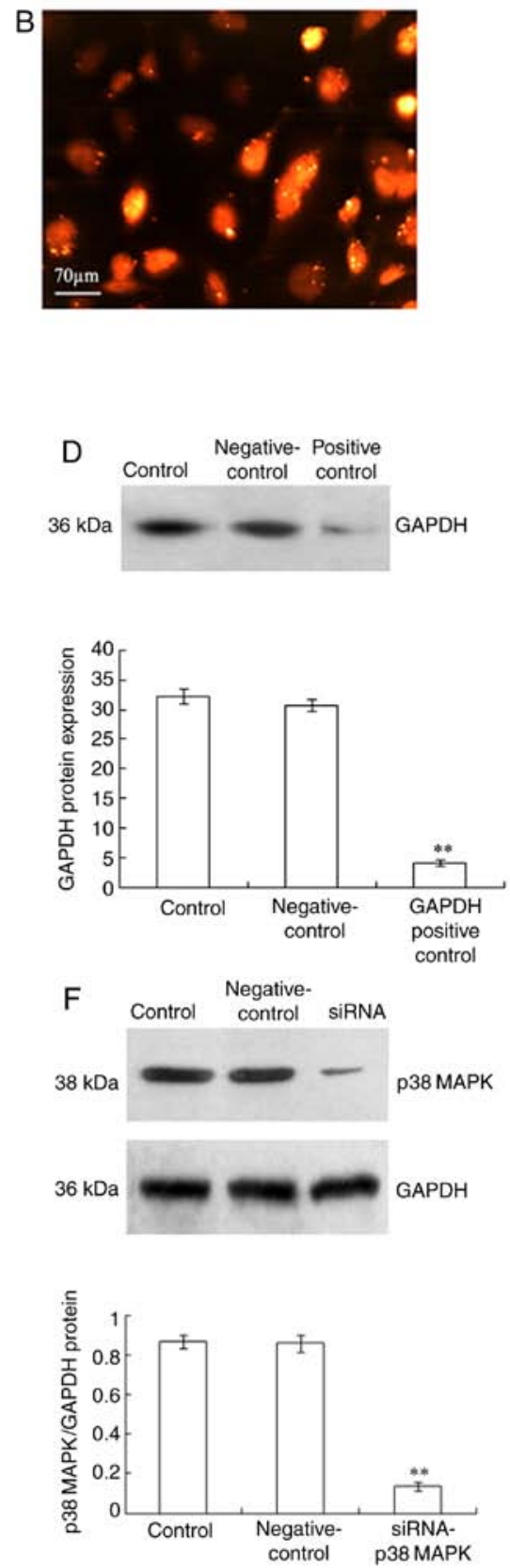

Figure 1. Silencing of p38 MAPK in LoVo cells. LoVo cells were transfected with siRNA-p38 MAPK (12.5 nmol/1), the negative control siRNA and the GAPDH positive control siRNA using Lipofectamine RNAiMAX. In the presence of Block-iT Alexa Fluor Red Fluorescent Control for 48 h, the LoVo cells were exposed to red light irradiation $\left(53.7 \mathrm{~J} / \mathrm{cm}^{2}\right)$, incubated for $3 \mathrm{~h}$ and then, the transfected cells were observed using $(\mathrm{A})$ an inverted microscope and $(\mathrm{B})$ a fluorescence microscope. Following transfection, the expression levels of p38 MAPK mRNA and p38 MAPK protein were analyzed using (C and E) reverse transcription-PCR and (D and F) immunoblot assay, respectively. The LoVo cells were treated with Lipofectamine RNAiMAX only as the control treatment. GAPDH was used as an internal control. The values presented are representative of three independent experiments $\left(\mathrm{mean} \pm \mathrm{standard}\right.$ deviation; ${ }^{* *} \mathrm{P}<0.01$, compared to the control treatment). Scale bar, $70 \mu \mathrm{m}$. siRNA, small interfering RNA; MAPK, mitogen-activated protein kinase.

Effect of TaPcZn-PDT on the apoptosis of LoVo cells. The effect of TaPcZn-PDT on the apoptosis of LoVo cells was detected in several ways. Firstly, the morphological changes of the cells were observed using an inverted microscope. Compared with the control group, the TaPcZn-PDT group had a significantly greater proportion of cells exhibiting morphological characteristics of apoptosis, such as cell shrinkage and an increased number of vacuoles in the cytoplasm (Fig. 2A). In addition, cell apoptosis was quantitated by flow cytometric analysis of Annexin V-FLUOS/PI double-stained cells. Compared with the control treatment,
TaPcZn-PDT significantly induced apoptosis of LoVo cells (Fig. 2B).

Crosstalk between p38 MAPK and caspase-9 regulates the TaPcZn-PDT-induced apoptosis of LoVo cells. To evaluate whether p38 MAPK and caspase-9 are involved in the T $\alpha$ PcZn-PDT-induced apoptosis of LoVo cells, an immunoblot assay was used to investigate the effect of TaPcZn-PDT on p38 MAPK, p-p38 MAPK and caspase-9 with or without siRNA-p38 MAPK or z-LEHD-fmk. Compared with the control treatment, T $\alpha$ PcZn-PDT increased p38 MAPK 


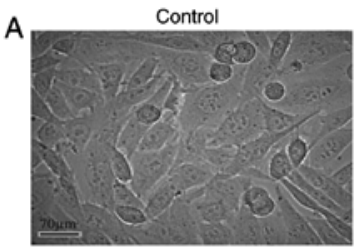

TaPcZn-PDT
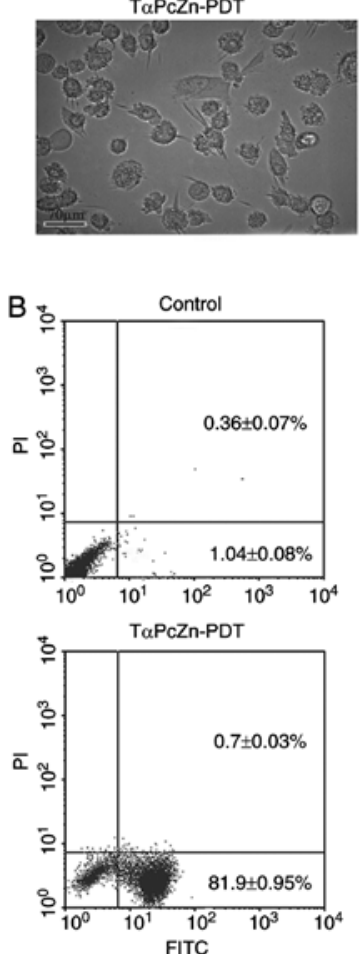

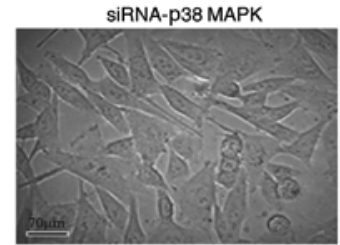

T $\alpha$ PcZn-PDT/siRNA-p38 MAPK
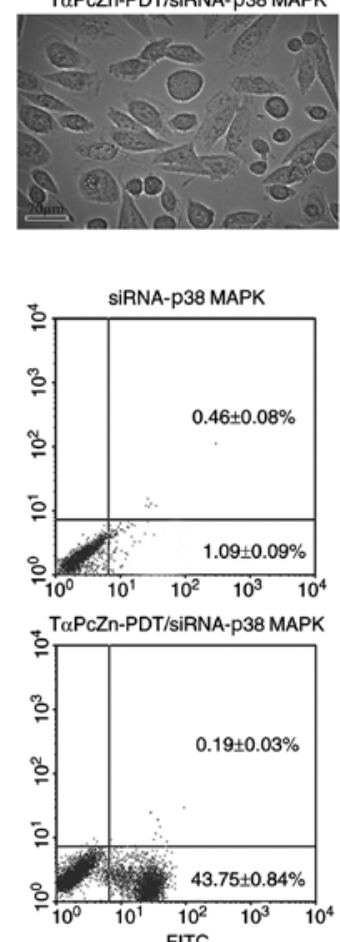

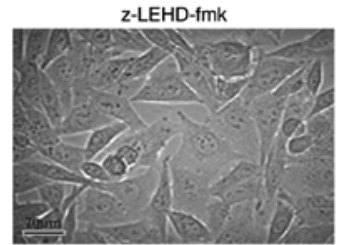

T $\alpha$ PcZn-PDT/Z-LEHD-fmk
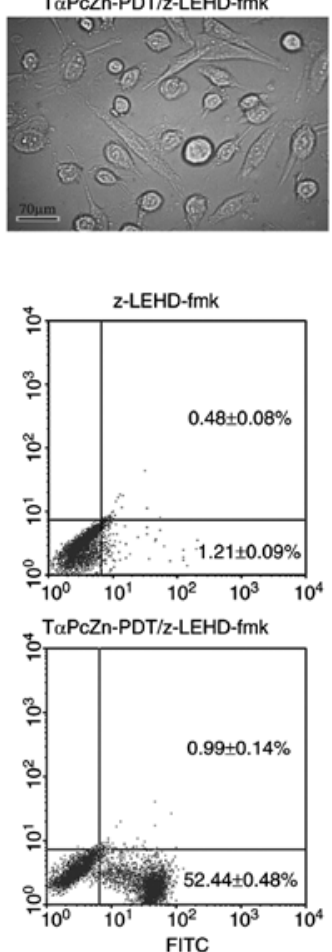

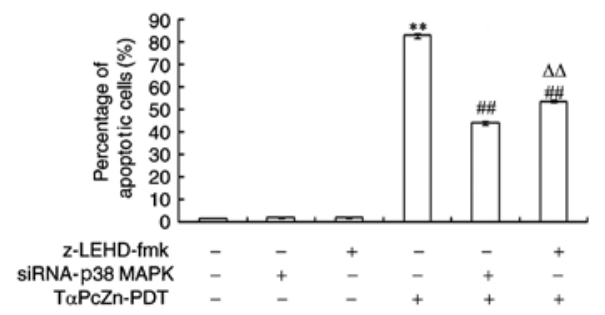

Figure 2. Effect of siRNA-p38 MAPK or z-LEHD-fmk on the T $\alpha$ PcZn-PDT-induced apoptosis of LoVo cells. In the absence or presence of siRNA-p38 MAPK $(12.5 \mathrm{nmol} / \mathrm{l})$ for $48 \mathrm{~h}$ or $\mathrm{z}-\mathrm{LEHD}-\mathrm{fmk}(10 \mu \mathrm{mol} / \mathrm{l})$ for $2.5 \mathrm{~h}$, LoVo cells were treated with T $\alpha \mathrm{PcZn}(54 \mu \mathrm{mol} / \mathrm{l})$, exposed to red light irradiation $\left(53.7 \mathrm{~J} / \mathrm{cm}^{2}\right)$, and then incubated for $3 \mathrm{~h}$. The morphology of the apoptotic cells was observed by (A) microscopy and the percentage of apoptotic cells was assayed by (B) flow cytometric analysis of Annexin V-FLUOS/PI double-stained cells. Scale bar, $70 \mu \mathrm{m}$. Values presented are representative of three independent experiments (mean \pm standard deviation; ${ }^{* *} \mathrm{P}<0.01$, compared with the control treatment; ${ }^{\# \#} \mathrm{P}<0.01$, compared with the T $\alpha \mathrm{PcZn}-\mathrm{PDT}$ treatment; ${ }^{\Delta \Delta} \mathrm{P}<0.01$, compared with the T $\alpha$ PcZn-PDT/siRNA-p38 MAPK treatment). siRNA, small interfering RNA; MAPK, mitogen-activated protein kinase; T $\alpha$ PcZn, tetra- $\alpha$-(4-carboxyphenoxy) phthalocyanine zinc; PDT, photodynamic therapy.

phosphorylation and active caspase-9, but had less influence on p38 MAPK (Fig. 3). However, compared with TaPcZn-PDT treatment only, siRNA-p38 MAPK decreased the level of p38 MAPK and p-p38 MAPK and z-LEHD-fmk decreased the level of activated caspase-9 (Fig. 3).

siRNA-p38 MAPK and z-LEHD-fmk were used to assess whether p38 MAPK and caspase-9 regulated apoptosis in the T $\alpha$ PcZn-PDT-treated LoVo cells. Compared with the T $\alpha$ PcZn-PDT treatment only, siRNA-p38 MAPK and z-LEHD-fmk inhibited the TaPcZn-PDT-induced apoptosis of LoVo cells (Fig. 2A and B). Additionally, the results revealed that siRNA-p38 MAPK had a more significant inhibitory effect on TaPcZn-PDT-induced apoptosis compared with that of z-LEHD-fmk (Fig. 2B).
To evaluate whether $\mathrm{p} 38$ MAPK regulated caspase- 9 and caspase-9 in turn regulated p38 MAPK, immunoblotting was performed to investigate the effect of siRNA-p38 MAPK on caspase- 9 and the effect of z-LEHD-fmk on p38 MAPK during the TaPcZn-PDT-induced apoptosis in LoVo cells. Compared with the TaPcZn-PDT treatment alone, siRNAp38 MAPK downregulated the expression of activated caspase-9 and z-LEHD-fmk downregulated the expression of p-p38 MAPK (Fig. 3).

To determine the manner in which p38 MAPK and caspase-9 regulated each other via crosstalk during the TaPcZn-PDT-induced apoptosis in LoVo cells, immunoprecipitation/immunoblot analysis was used to investigate the interaction between p38 MAPK and caspase-9 with or 

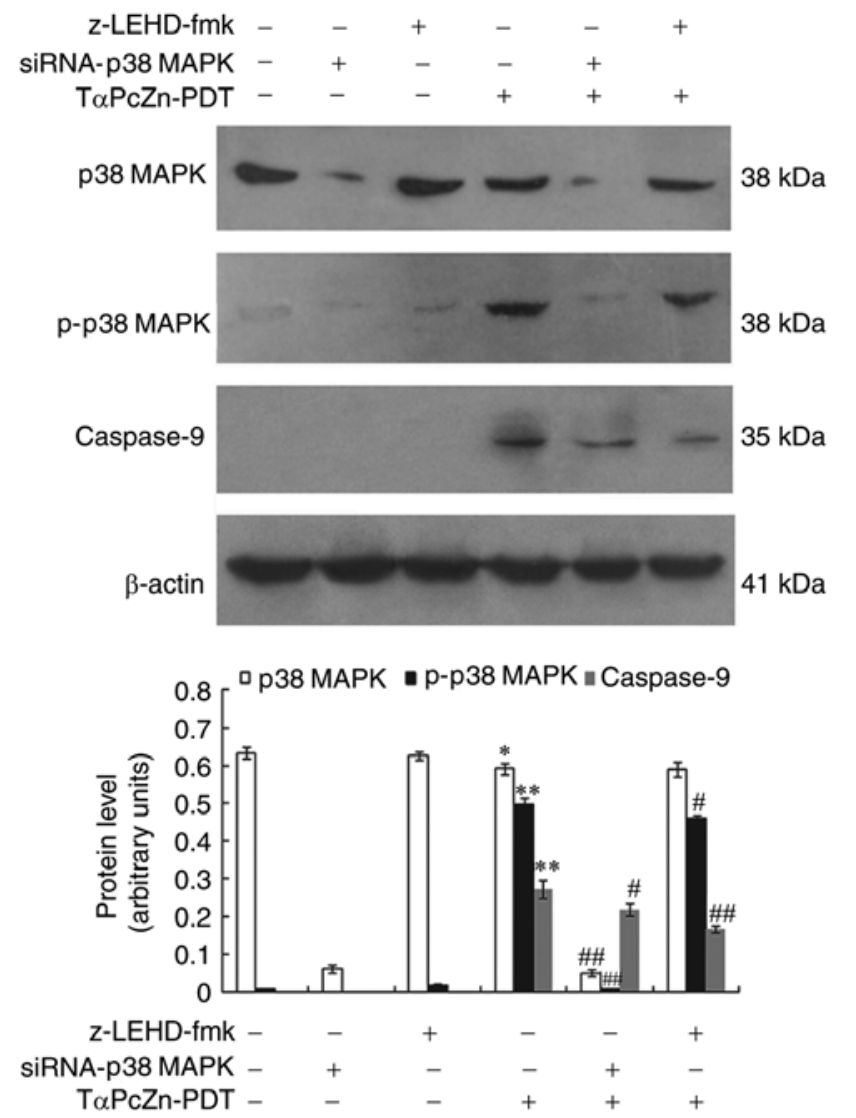

Figure 3. Changes in p38 MAPK, p-p38 MAPK and caspsase-9 levels in response to treatment with TaPcZn-PDT, with or without siRNA-p38 MAPK or z-LEHD-fmk, in LoVo cells. Following treatment with siRNA-p38 MAPK $(12.5 \mathrm{nmol} / \mathrm{l})$ for $48 \mathrm{~h}$ or $\mathrm{z}$-LEHD-fmk $(10 \mu \mathrm{mol} / \mathrm{l})$ for $2.5 \mathrm{~h}$, the LoVo cells were treated with TaPcZn $(54 \mu \mathrm{mol} / \mathrm{l})$, exposed to red light irradiation $\left(53.7 \mathrm{~J} / \mathrm{cm}^{2}\right)$ and then incubated for $3 \mathrm{~h}$. The expression of p38 MAPK, p-P38MAPK and cleaved caspase- 9 was analyzed by an immunoblot assay. The values presented are representative of three independent experiments (mean \pm standard deviation; ${ }^{*} \mathrm{P}<0.05,{ }^{* *} \mathrm{P}<0.01$, compared to the control treatment; ${ }^{\#} \mathrm{P}<0.05,{ }^{\# \#} \mathrm{P}<0.01$, compared with the TaPcZn-PDT treatment). siRNA, small interfering RNA; MAPK, mitogen-activated protein kinase; TaPcZn, tetra- $\alpha$-(4-carboxyphenoxy) phthalocyanine zinc; PDT, photodynamic therapy.

without siRNA-p38 MAPK or z-LEHD-fmk. Compared with

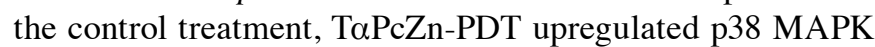
and caspase-9 (Fig. 4A), indicating that TaPcZn-PDT induced the formation of $\mathrm{p} 38 \mathrm{MAPK} / \mathrm{caspase}-9$ complexes. However, compared with the TaPcZn-PDT treatment alone, siRNA-p38 MAPK or z-LEHD-fmk downregulated p38 MAPK or caspase-9, respectively (Fig. 4A). Furthermore, the interaction between $\mathrm{p} 38$ MAPK and caspase-9 in the TaPcZn-PDT-induced apoptosis of LoVo cells was detected by an LSPR assay. Firstly, the LSPR signal shift was used to assess the interaction between $\mathrm{p} 38 \mathrm{MAPK}$ and the total cellular protein. Compared with the control treatment, TaPcZn-PDT markedly increased the LSPR signal shift (Fig. 4B), indicating that p38 MAPK bound to total protein. Secondly, the LSPR signal shift was used to detect the interaction between caspase- 9 and the total protein/p38 MAPK complexes. Compared with the control treatment, TaPcZn-PDT obviously increased the LSPR signal shift (Fig. 4C), indicating that caspase- 9 bound to the total protein/p38 MAPK complexes and to $\mathrm{p} 38$ MAPK.
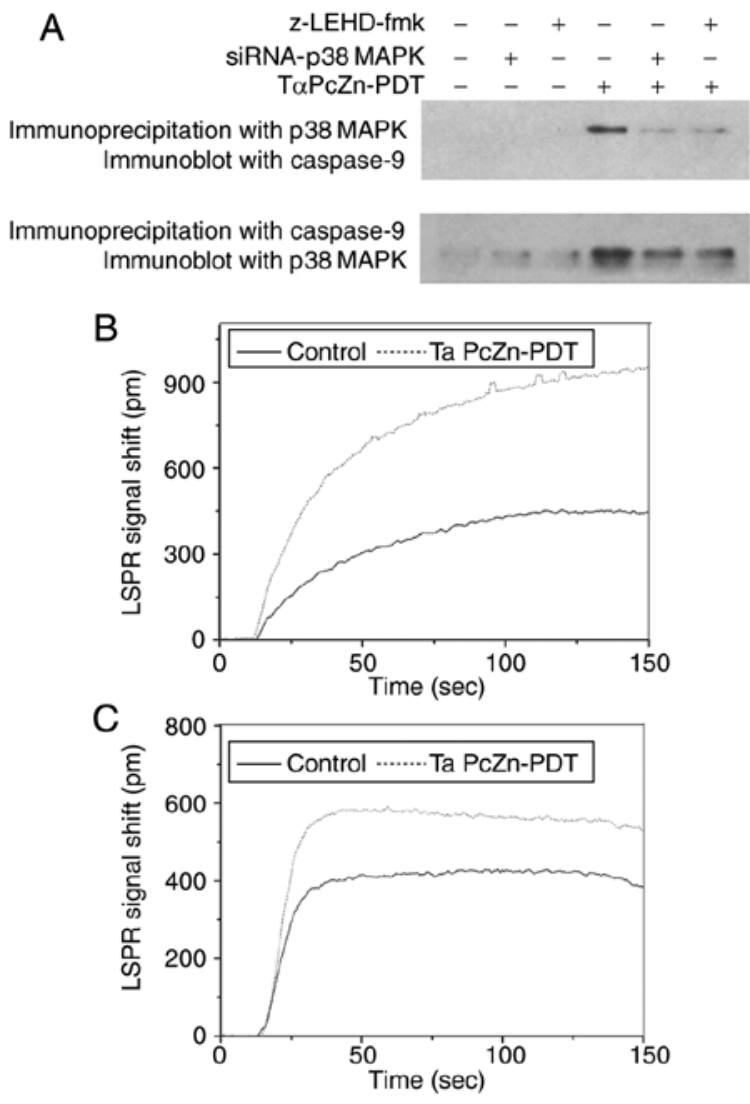

Figure 4. Interaction between p38 MAPK and caspase-9 in the TaPcZn-PDT-induced apoptosis of LoVo cells. (A) In the absence or presence of siRNA-p38 MAPK $(12.5 \mathrm{nmol} / \mathrm{l})$ for $48 \mathrm{~h}$ or z-LEHD-fmk $(10 \mu \mathrm{mol} / \mathrm{l})$ for $2.5 \mathrm{~h}$, LoVo cells were treated with TaPcZn $(54 \mu \mathrm{mol} / \mathrm{l})$, exposed to red light irradiation $\left(53.7 \mathrm{~J} / \mathrm{cm}^{2}\right)$ and then incubated for $3 \mathrm{~h}$. Immunoprecipitates with the p38 MAPK antibody or caspase- 9 antibody from LoVo cells were separated by $10 \%$ sodium dodecyl sulfate-polyacrylamide gel electrophoresis (SDS-PAGE) and then, immunoblotted with the caspase- 9 antibody or p38 MAPK antibody. (B) Real-time signal shift of interaction between the anti-p38 MAPK and the total protein from the LoVo cells and (C) real-time signal shift of interaction between the anti-caspase-9 and anti-p38 MAPK/total LoVo cell protein complex were assayed by localized surface plasmon resonance. The resonance wavelength was obtained by fitting localized surface plasmon resonance signals to the Lorentzian equation. siRNA, small interfering RNA; MAPK, mitogen-activated protein kinase; T $\alpha$ PcZn, tetra- $\alpha$-(4-carboxyphenoxy) phthalocyanine zinc; PDT, photodynamic therapy.

Crosstalk between $p 38$ MAPK and caspase-9 regulates mitochondria in TaPcZn-PDT-induced apoptosis of LoVo cells. To assess whether the crosstalk between $\mathrm{p} 38$ MAPK and caspase- 9 regulates mitochondria during the TaPcZn-PDT-induced apoptosis of LoVo cells, a JC-I assay was used to detect the influence of T $\alpha$ PcZn-PDT on $\Delta \Psi \mathrm{m}$ with or without siRNA-p38 MAPK or z-LEHD-fmk. Compared with the control treatment, TaPcZn-PDT increased the number of green fluorescent apoptotic cells (Fig. 5A) and decreased the ratio of red/green fluorescence intensity (Fig. 5B). However, compared with T $\alpha$ PcZn-PDT treatment only, siRNA-p38 MAPK or z-LEHD-fmk decreased the number of green fluorescent apoptotic cells (Fig. 5A) and increased the ratio of red/green fluorescence intensity (Fig. 5B).

To further assess whether the crosstalk between p38 MAPK and caspase-9 regulates mitochondria during the TaPcZn-PDT-induced apoptosis of the LoVo cells, immunoblotting was performed to examine the levels of 


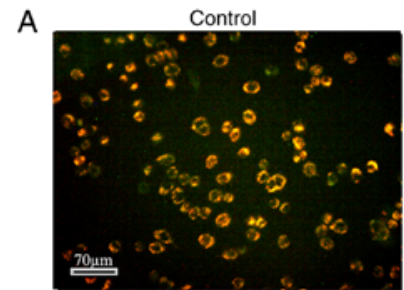

TaPcZn-PDT

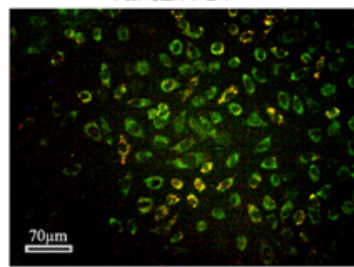

B
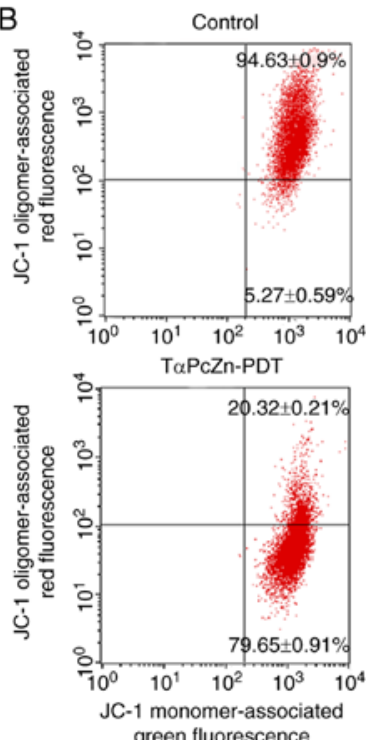

green fluorescence

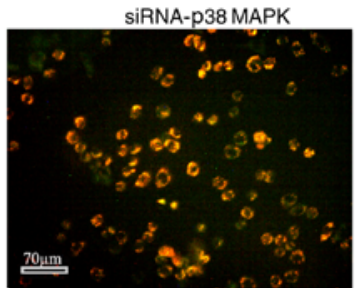

T $\alpha$ PcZn-PDT/siRNA-p38 MAPK
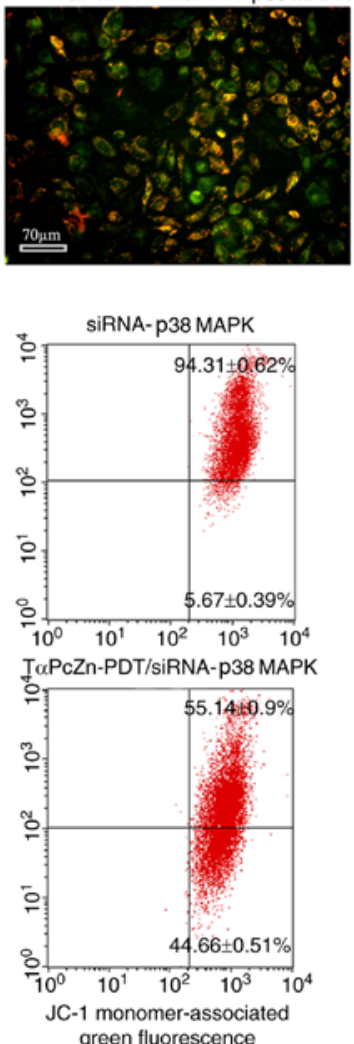

green fluorescence

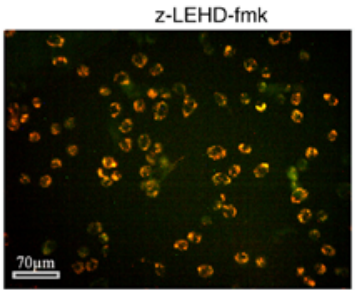

TaPcZn-PDT/z-LEHD-fmk

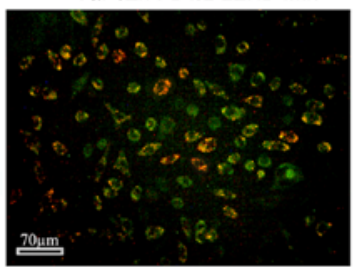

z-LEHD-fmk

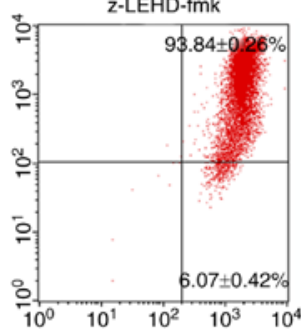

TaPcZn-PDT/z-LEHD-fmk

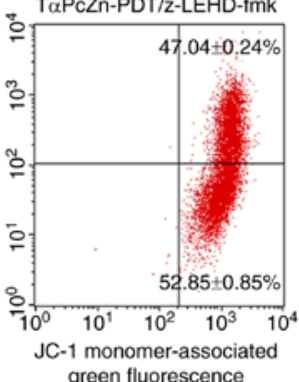

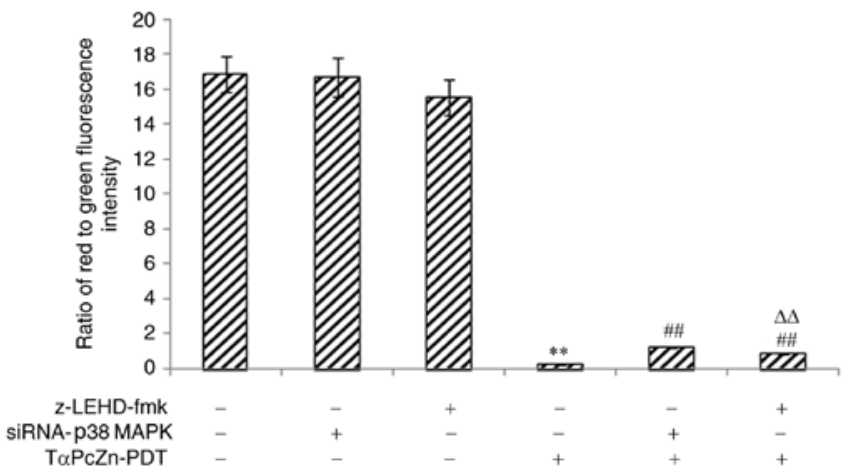

Figure 5. Effect of T $\alpha$ PcZn-PDT treatment, with or without siRNA-p38 MAPK or z-LEHD-fmk, on $\triangle \Psi \mathrm{m}$ in the LoVo cells analyzed by JC-1 staining assay. In the absence or presence of siRNA-P38MAPK $(12.5 \mathrm{nmol} / \mathrm{l})$ for $48 \mathrm{~h}$ or $\mathrm{z}$-LEHD-fmk $(10 \mu$ mol/l) for $2.5 \mathrm{~h}$, the LoVo cells were treated with T $\alpha \mathrm{PcZn}$ $(54 \mu \mathrm{mol} / \mathrm{l})$, exposed to red light irradiation $\left(53.7 \mathrm{~J} / \mathrm{cm}^{2}\right)$ and then incubated for $3 \mathrm{~h}$. (A) The red/green fluorescence intensity and (B) the ratio of red to green fluorescence intensity in LoVo cells were detected by JC-1 assay using fluorescence microscopy and flow cytometry, respectively. Scale bar, $70 \mu \mathrm{m}$. Values presented are representative of three independent experiments (mean \pm standard deviation; ${ }^{* *} \mathrm{P}<0.01$, compared with control treatment; ${ }^{\# \#} \mathrm{P}<0.01$, compared with T $\alpha$ PcZn-PDT treatment; ${ }^{\Delta \Delta} \mathrm{P}<0.01$, compared with the T $\alpha$ PcZn-PDT/siRNA-p38 MAPK treatment). siRNA, small interfering RNA; MAPK, mitogenactivated protein kinase; $\Delta \Psi \mathrm{m}$, mitochondrial membrane potential; T $\alpha \mathrm{PcZn}$, tetra- $\alpha$-(4-carboxyphenoxy) phthalocyanine zinc; PDT, photodynamic therapy.

factors and proteins associated with mitochondria, including Bcl-2, Bax, AIF, Cyto $c$, Bid and caspase-3, with or without siRNA-p38 $M A P K$ or z-LEHD-fmk treatment. Compared with the control treatment, T $\alpha$ P Zn-PDT significantly downregulated the expression of $\mathrm{Bcl}-2$, upregulated the expression of Bax, promoted the release of AIF and Cyto $c$ and activated Bid and caspase-3 (Fig. 6A-C). However, compared with the T $\alpha$ PcZn-PDT treatment alone, siRNA-p38 MAPK or z-LEHD-fmk attenuated the effects of TaPcZn-PDT on Bcl-2, Bax, AIF, Cyto $c$, Bid and caspase-3 (Fig. 6A-C). In addition, the results revealed that the inhibitory effect of siRNA-p38 MAPK on $\triangle \Psi \mathrm{m}, \mathrm{Bcl}-2, \mathrm{Bax}, \mathrm{AIF}$, Cyto $c$, 
A

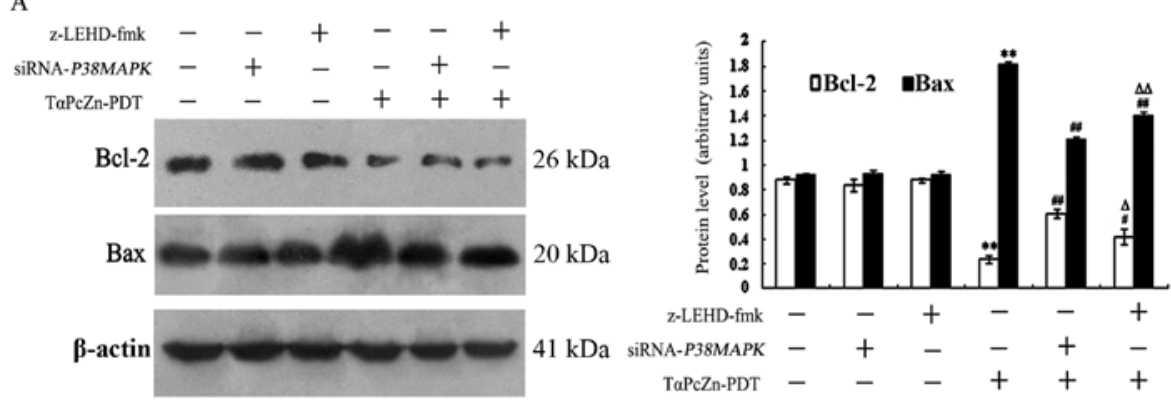

B
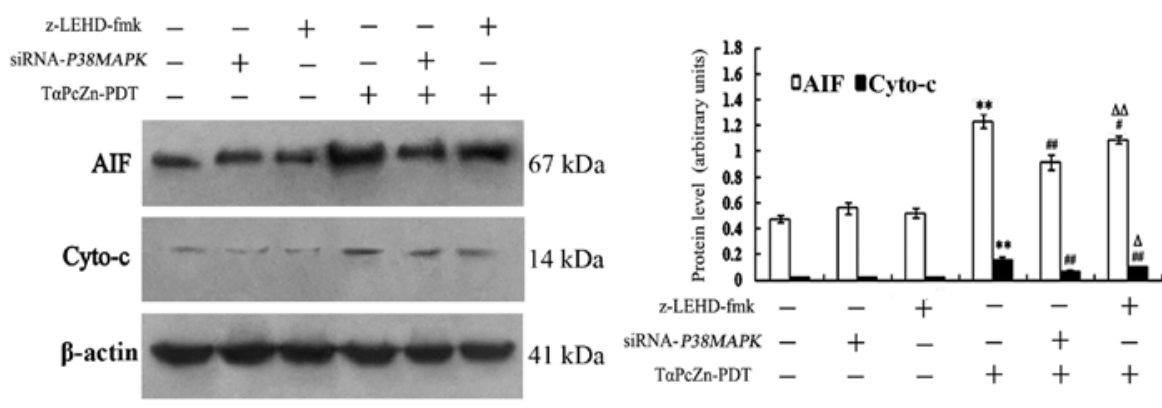

C
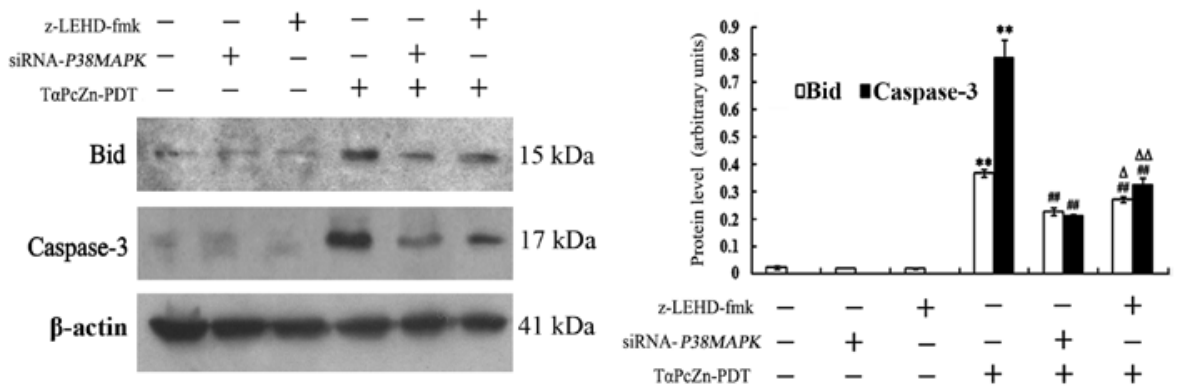

Figure 6. Effect of TaPcZn-PDT treatment, with or without siRNA-p38 MAPK or z-LEHD-fmk, on Bcl-2, Bax, AIF, Cyto $c$, Bid and caspase-3 levels in LoVo cells analyzed by immunoblot assay. In the absence or presence of siRNA-p38 MAPK (12.5 nmol/1) for $48 \mathrm{~h}$ or z-LEHD-fmk (10 $\mu \mathrm{mol} / 1)$ for $2.5 \mathrm{~h}, \mathrm{LoVo}$ cells were treated with TaPcZn (54 $\mu \mathrm{mol} / 1)$, exposed to red light irradiation $\left(53.7 \mathrm{~J} / \mathrm{cm}^{2}\right)$ and then incubated for $3 \mathrm{~h}$. The expression of (A) Bcl-2 and Bax, (B) AIF and Cyto $c$ and $(\mathrm{C})$ Bid and caspase-3 was analyzed by immunoblot assay. Values presented are representative of three independent experiments (mean \pm standard deviation; ${ }^{* *} \mathrm{P}<0.01$, compared with the control treatment; ${ }^{\# \mathrm{P}}<0.05,{ }^{\sharp \# t} \mathrm{P}<0.01$, compared with the TaPcZn-PDT treatment; ${ }^{\Delta} \mathrm{P}<0.05,{ }^{\Delta \Delta} \mathrm{P}<0.01$, compared with the T $\alpha$ PcZn-PDT/siRNA-p38 MAPK treatment). siRNA, small interfering RNA; MAPK, mitogen-activated protein kinase; AIF, apoptosis-inducing factor; Cyto $c$, cytochrome $c$; T $\alpha \mathrm{PcZn}$, tetra- $\alpha$-(4-carboxyphenoxy) phthalocyanine zinc; PDT, photodynamic therapy.

Bid and caspase- 3 was more significant than the effects of z-LEHD-fmk on these factors in the TaPcZn-PDT-induced apoptosis of LoVo cells (Figs. 5B and 6A-C).

\section{Discussion}

Accumulating evidence has revealed that phthalocyanine-PDT induces apoptosis of tumor cells $(11,35)$. However, it was unclear whether TaPcZn-PDT induced the apoptosis of the LoVo cells. Therefore, the present study performed an initial investigation of this, confirming that TaPcZn-PDT induced apoptosis of LoVo cells.

p38 MAPK is an important signal in stress responses and caspase-9 is a key initiator in the mitochondrial apoptotic pathway (36-40). Recent studies revealed that p38 MAPK and caspase-9 were involved in the apoptotic process of tumor cells treated with phthalocyanine-PDT $(8,23,24,32,41)$. However, the mechanism through which p38 MAPK and caspase-9 regulated the TaPcZn-PDT-induced apoptosis of
LoVo cells remains unclear. Therefore, we examined the effect of TaPcZn-PDT on p38 MAPK, p-p38 MAPK and caspase-9 levels, in combination with siRNA-p38 MAPK or z-LEHD-fmk. The results indicated that TaPcZn-PDT activated p38 MAPK and caspase-9, but siRNA-p38 MAPK and z-LEHD-fmk both reduced the level of activated p38 MAPK and caspase- 9 , indicating that the activation of p38 MAPK and caspase-9 may be involved in the TaPcZn-PDT-induced apoptosis of LoVo cells. To assess whether p38 MAPK and caspase-9 regulated apoptosis in the TaPcZn-PDT-treated LoVo cells, we analyzed the effect of siRNA-p38 MAPK and z-LEHD-fmk on apoptosis. We observed that both siRNA-p38 MAPK and z-LEHD-fmk reduced apoptosis of T $\alpha$ PcZn-PDT-treated LoVo cells, indicating that activated p38 MAPK and caspase-9 are essential for TaPcZn-PDT-induced apoptosis of LoVo cells.

Certain studies have reported that p38 MAPK regulates caspase-9 during drug-induced apoptosis of tumor cells $(42,43)$. However, whether p38 MAPK and caspase-9 regulate each 
other has not been ascertained in the TaPcZn-PDT-induced apoptosis of LoVo cells. Therefore, we examined the effect of siRNA-p38 MAPK on caspase-9 and the effect of $\mathrm{z}$-LEHD-fmk on p38 MAPK during TaPcZn-PDT-induced apoptosis of LoVo cells. The results revealed that siRNA-p38 MAPK decreased the activation of caspase- 9 and that z-LEHD-fmk decreased the activation of p38 MAPK, indicating that the crosstalk regulation between p38 MAPK and caspase- 9 is involved in the TaPcZn-PDT-induced apoptosis of LoVo cells. In addition, these findings indicated that the inhibitory effect of siRNA-p38 MAPK on the T $\alpha$ PcZn-PDT-induced apoptosis was more significant than the effect of z-LEHD-fmk on apoptosis, revealing that p38 MAPK may have an important regulatory role in the crosstalk between p38 MAPK and caspase- 9 during apoptosis of these treated cells. To determine the manner in which p38 MAPK and caspase-9 regulate each other during the T $\alpha$ PcZn-PDT-induced apoptosis of LoVo cells, we investigated the interaction between p38 MAPK and caspase-9 with or without siRNA-p38 MAPK or z-LEHD-fmk. The results revealed that T $\alpha \mathrm{PcZn}$-PDT induced the formation of p38 MAPK/caspase-9 complexes, but siRNA-p38 MAPK or z-LEHD-fmk both decreased the formation of p38 MAPK/caspase-9 complexes, indicating that p38 MAPK may bind to caspase- 9 and that p38 MAPK or caspase-9 can regulate their interaction. All of the aforementioned results indicated that p38 MAPK may play an important regulatory role in the crosstalk between p38 MAPK and caspase-9 and that direct interaction between $\mathrm{p} 38$ MAPK and caspase- 9 may regulate apoptosis in the T $\alpha$ PcZn-PDT-treated LoVo cells.

Previous studies revealed that mitochondria play a crucial regulatory role in phthalocyanine-PDT-induced apoptosis $(23,24)$ and that p38 MAPK and caspase- 9 regulated mitochondria during cell apoptosis (44-48). However, it was not clear whether p38 MAPK and caspase-9 regulated mitochondria in the TaPcZn-PDT-induced apoptosis of LoVo cells. Therefore, the effect of the T $\alpha$ PcZn-PDT treatment in combination with siRNA-p38 MAPK or z-LEHD-fmk on $\triangle \Psi \mathrm{m}$ and mitochondria-related factors and proteins (Bcl-2, Bax, AIF, Cyto $c$, Bid and caspase-3) was investigated in the present study. The findings revealed that T $\alpha \mathrm{PcZn}-\mathrm{PDT}$ resulted in the reduction of $\Delta \Psi \mathrm{m}$, the downregulation of Bcl-2, the upregulation of Bax expression, the release of AIF and Cyto $c$ and the activation of $\mathrm{Bid}$ and caspase-3, indicating the involvement of mitochondria in the process of T $\alpha$ PcZn-PDT-induced apoptosis. However, siRNA-p38 MAPK and z-LEHD-fmk both attenuated the effects of T $\alpha$ PcZn-PDT on $\Delta \Psi \mathrm{m}, \mathrm{Bcl}-2, \mathrm{Bax}$, AIF, Cyto $c$, Bid and caspase-3, indicating that the crosstalk between $\mathrm{p} 38$ MAPK and caspase-9 may regulate mitochondria during T $\alpha$ PcZn-PDT-induced apoptosis of LoVo cells. In addition, the results revealed that siRNA-p38 MAPK had a more significant inhibitory effect on $\triangle \Psi \mathrm{m}, \mathrm{Bcl}-2, \mathrm{Bax}, \mathrm{AIF}$, Cyto $c$, Bid and caspase-3 than the effect of z-LEHD-fmk, indicating that $\mathrm{p} 38$ MAPK has a major regulatory role in the crosstalk between p38 MAPK and caspase- 9 during the T $\alpha$ PcZn-PDT-induced apoptosis in this cell type. As caspase-9 is the downstream of mitochondria within the apoptosis pathway, caspase- 9 may regulate the mitochondria upstream by directly influencing p38 MAPK during the crosstalk between p38 MAPK and caspase-9, which may explain the reason why p38 MAPK had a more significant influence on mitochondria than caspase-9 in the crosstalk between p38 MAPK and caspase-9.

In conclusion, our findings indicated that p38 MAPK in the crosstalk between $\mathrm{p} 38$ MAPK and caspase-9 may play a major regulatory role and direct crosstalk between p38 MAPK and caspase-9 may regulate mitochondria-mediated apoptosis in the T $\alpha$ PcZn-PDT-treated LoVo cells.

\section{Acknowledgements}

The project was supported by the Natural Science Foundation of Heilongjiang Province (no. ZD201318).

\section{References}

1. Lucena SR, Salazar N, Gracia-Cazaña T, Zamarrón A, González S, Juarranz Á and Gilaberte Y: Combined treatments with photodynamic therapy for non-melanoma skin cancer. Int J Mol Sci 16: 25912-25933, 2015

2. Acedo P, Stockert JC, Cañete M and Villanueva A: Two combined photosensitizers: A goal for more effective photodynamic therapy of cancer. Cell Death Dis 5: e1122, 2014.

3. Zheng Y, Zhang Y, Chen D, Chen H, Lin L, Zheng C and Guo Y: Monascus pigment rubropunctatin: A potential dual agent for cancer chemotherapy and phototherapy. J Agric Food Chem 64: 2541-2548, 2016.

4. Kessel D: Death pathways associated with photodynamic therapy. Med Laser Appl 21: 219-224, 2006.

5. Yslas EI,Durantini EN and Rivarola VA: Zinc-(II) 2,9,16,23-tetrakis (methoxy) phthalocyanine: Potential photosensitizer for use in photodynamic therapy in vitro. Bioorg Med Chem 15: 46514660, 2007.

6. Xia C, Wang Y, Chen W, Yu W, Wang B and Li T: New hydrophilic/lipophilic tetra- $\alpha$-(4-carboxyphenoxy) phthalocyanine zinc-mediated photodynamic therapy inhibits the proliferation of human hepatocellular carcinoma Bel-7402 cells by triggering apoptosis and arresting cell cycle. Molecules 16 : 1389-1401, 2011

7. Zhao Z, Chan PS, Li H, Wong KL, Wong RN, Mak NK, Zhang J, Tam HL, Wong WY, Kwong DW, et al: Highly selective mitochondria-targeting amphiphilic silicon(IV) phthalocyanines with axially ligated rhodamine B for photodynamic therapy. Inorg Chem 51: 812-821, 2012.

8. Wang Y, Xia C, Chen W, Chen Y, Wang Y and Li T. Autoregulatory feedback mechanism of P38MAPK/Caspase-8 in Photodynamic Therapy-Hydrophilic/Lipophilic Tetra- $\alpha$-(4-carboxyphenoxy) phthalocyanine zinc-induced apoptosis of human hepatocellular carcinoma Bel-7402 Cells. Int J Photoenergy 2014: 163813, 2014. doi: org/10.1155/2014/163813.

9. Cakir D, Göksel M, Çakır V, Durmuş M, Biyiklioglu Z and Kantekin H. Amphiphilic zinc phthalocyanine photosensitizers: synthesis, photophysicochemical properties and in vitro studies for photodynamic therapy. Dalton Trans 44: 96469658,2015

10. Seervi M and Xue D: Mitochondrial cell death pathways in caenorhabiditis elegans. Curr Top Dev Biol 114: 43-65, 2015.

11. Mfouo-Tynga I and Abrahamse $\mathrm{H}$ : Cell death pathways and phthalocyanine as an efficient agent for photodynamic cancer therapy. Int J Mol Sci 16: 10228-10241, 2015.

12. Sevrioukova IF: Apoptosis-inducing factor: Structure, function, and redox regulation. Antioxid Redox Signal 14: 2545-2579, 2011.

13. Doti N, Reuther C, Scognamiglio PL, Dolga AM, Plesnila N, Ruvo M and Culmsee C: Inhibition of the AIF/CypA complex protects against intrinsic death pathways induced by oxidative stress. Cell Death Dis 5: e993, 2014.

14. Karch J and Molkentin JD: Regulated necrotic cell death: The passive aggressive side of Bax and Bak. Circ Res 116: 1800-1809, 2015.

15. Gillies LA and Kuwana T: Apoptosis regulation at the mitochondrial outer membrane. J Cell Biochem 115: 632-640, 2014.

16. Juric V, Chen CC and Lau LF: TNFa-induced apoptosis enabled by CCN1/CYR61: Pathways of reactive oxygen species generation and cytochrome c release. PLoS One 7: e31303, 2012. 
17. Ameeramja J, Panneerselvam L, Govindarajan V, Jeyachandran S, Baskaralingam V and Perumal E: Tamarind seed coat ameliorates fluoride induced cytotoxicity, oxidative stress, mitochondrial dysfunction and apoptosis in A549 cells. J Hazard Mater 301: 554-565, 2016.

18. Park HS, Hwang HJ, Kim G-Y, Cha H-J, Kim W-J, Kim ND, Yoo YH and Choi YH: Induction of apoptosis by fucoidan in human leukemia U937 cells through activation of p38 MAPK and modulation of Bcl-2 family. Mar Drugs 11: 2347-2364, 2013.

19. Kong D, Zheng T, Zhang M, Wang D, Du S, Li X, Fang J and Cao X: Static mechanical stress induces apoptosis in rat endplate chondrocytes through MAPK and mitochondria-dependent caspase activation signaling pathways. PLoS One 8: e69403, 2013.

20. Tait SWG and Green DR: Mitochondrial regulation of cell death. Cold Spring Harb Perspect Biol 5: a008706, 2013.

21. Hsiao P-C, Chou YE, Tan P, Lee WJ, Yang SF, Chow JM, Che HY, Lin CH, Lee LM and Chien MH: Pterostilbene simultaneously induced G0/G1-phase arrest and MAPK-mediated mitochondrial-derived apoptosis in human acute myeloid leukemia cell lines. PLoS One 9: e105342, 2014.

22. Tor YS, Yazan LS, Foo JB, Wibowo A, Ismail N, Cheah YK, Abdullah R, Ismail M, Ismail IS and Yeap SK: Induction of apoptosis in MCF-7 cells via oxidative stress generation, mitochondria-dependent and caspase-independent pathway by ethyl acetate extract of dillenia suffruticosa and its chemical profile. PLoS One 10: e0127441, 2015.

23. Shao J, Dai Y, Zhao W, Xie J, Xue J, Ye J and Jia L: Intracellular distribution and mechanisms of actions of photosensitizer Zinc(II)-phthalocyanine solubilized in Cremophor EL against human hepatocellular carcinoma HepG2 cells. Cancer Lett 330 49-56, 2013.

24. Marino J, García Vior MC, Furmento VA, Blank VC, Awruch J and Roguin LP: Lysosomal and mitochondrial permeabilization mediates zinc(II) cationic phthalocyanine phototoxicity. Int J Biochem Cell Biol 45: 2553-2562, 2013.

25. Jeong HS, Choi HY, Lee ER, Kim JH, Jeon K, Lee HJ and Cho SG: Involvement of caspase-9 in autophagy-mediated cell survival pathway. Biochim Biophys Acta 1813: 80-90, 2011

26. Han J, Hou W, Goldstein LA, Stolz DB, Watkins SC and Rabinowich H: A Complex between Atg7 and Caspase-9: A novel mechanism of cross-regulation between autophagy and apoptosis. J Biol Chem 289: 6485-6497, 2014.

27. Johnson GL and Lapadat R: Mitogen-activated protein kinase pathways mediated by ERK, JNK, and p38 protein kinases. Science 298: 1911-1912, 2002.

28. Sui X, Kong N, Ye L, Han W, Zhou J, Zhang Q, He C and Pan H: p38 and JNK MAPK pathways control the balance of apoptosis and autophagy in response to chemotherapeutic agents. Cancer Lett 344: 174-179, 2014

29. Bu HQ, Liu DL, Wei WT, Chen L, Huang H, Li Y and Cui JH: Oridonin induces apoptosis in SW1990 pancreatic cancer cells via p53- and caspase-dependent induction of p38 MAPK. Oncol Rep 31: 975-982, 2014.

30. Lewis TS, Shapiro PS and Ahn NG: Signal transduction through MAP kinase cascades. Adv Cancer Res 74: 49-139, 1998.

31. Xue L, He J and Oleinick NL: Promotion of photodynamic therapy-induced apoptosis by stress kinases. Cell Death Differ 6 : 855-864, 1999.

32. Whitacre CMFD, Feyes DK, Satoh T, Grossmann J, Mulvihill JW, Mukhtar $\mathrm{H}$ and Oleinick NL: Photodynamic therapy with the phthalocyanine photosensitizer Pc 4 of SW480 human colon cancer xenografts in athymic mice. Clin Cancer Res 6: 2021-2027, 2000.

33. WuHY,Chen W,LiT,Wang Y,XiaCHandLiXL: Study onsynthesis and antineoplastic activity of $\alpha$-tetra-(4-carboxyphenoxy) phthalocyanine zinc. J Liaoning Normal Univ (Natural Science Edition) 1: 94-97, 2009 (In Chinese).
34. Bi MC, Rosen R, Zha RY, McCormick SA, Song E and Hu DN Zeaxanthin induces apoptosis in human uveal melanoma cells through Bcl-2 family proteins and intrinsic apoptosis pathway. Evid Based Complement Alternat Med 2013: 205082, 2013.

35. Kuzyniak W, Ermilov EA, Atilla D, Gürek AG, Nitzsche B, Derkow K, Hoffmann B, Steinemann G, Ahsen V and Höpfner M: Tetra-triethyleneoxysulfonyl substituted zinc phthalocyanine for photodynamic cancer therapy. Photodiagn Photodyn Ther 13: $148-157,2016$.

36. Kim JY, Yu SJ, Oh HJ, Lee JY, Kim Y and Sohn J: Panaxydol induces apoptosis through an increased intracellular calcium level, activation of JNK and p38 MAPK and NADPH oxidase-dependent generation of reactive oxygen species. Apoptosis 16: 347-358, 2011.

37. Festa M, Capasso A, D’Acunto CW, Masullo M, Rossi AG, Pizza $\mathrm{C}$ and Piacente S: Xanthohumol induces apoptosis in human malignant glioblastoma cells by increasing reactive oxygen species and activating MAPK pathways. J Nat Prod 74: 2505-2513, 2011 .

38. Liu Y, Zhang S, Su D, Liu J, Cheng Y, Zou L, Li W and Jiang Y: Inhibiting (pro)renin receptor-mediated p38 MAPK signaling decreases hypoxia/reoxygenation-induced apoptosis in $\mathrm{H} 9 \mathrm{c} 2$ cells. Mol Cell Biochem 403: 267-276, 2015.

39. Hui K, Yang Y, Shi K, Luo H, Duan J, An J, Wu P, Ci Y, Shi L and Xu C: The p38 MAPK-regulated PKD1/CREB/Bcl-2 pathway contributes to selenite-induced colorectal cancer cell apoptosis in vitro and in vivo. Cancer Lett 354: 189-199, 2014.

40. Zhao W, Yang Y, Zhang YX, Zhou C, Li HM, Tang YL, Liang $\mathrm{XH}$, Chen $\mathrm{T}$ and Tang YJ: Fluoride-containing podophyllum derivatives exhibit antitumor activities through enhancing mitochondrial apoptosis pathway by increasing the expression of caspase-9 in HeLa cells. Sci Rep 5: 17175, 2015.

41. Wright DB and Loftus EF: Measuring dissociation: Comparison of alternative forms of the dissociative experiences scale. Am J Psychol 112: 497-519, 1999.

42. Sreekanth GP, Chuncharunee A, Sirimontaporn A, Panaampon J, Noisakran S, Yenchitsomanus PT and Limjindaporn T: SB203580 modulates $\mathrm{p} 38$ MAPK signaling and dengue virus-induced liver injury by reducing MAPKAPK2, HSP27, and ATF2 phosphorylation. PLoS One 11: e0149486, 2016.

43. Zou S, Wang C, Cui Z, Guo P, Meng Q, Shi X, Gao Y, Yang G and Han Z: $\beta$-Elemene induces apoptosis of human rheumatoid arthritis fibroblast-like synoviocytes via reactive oxygen speciesdependent activation of p38 mitogen-activated protein kinase. Pharmacol Rep 68: 7-11, 2016.

44. Park GB, Kim YS, Lee HK, Song H, Kim S, Cho DH and Hur DY: Reactive oxygen species and p38 MAPK regulate Bax translocation and calcium redistribution in salubrinal-induced apoptosis of EBV-transformed B cells. Cancer Lett 313: 235-248, 2011.

45. Yang JB, Khan M, He YY, Yao M, Li YM, Gao HW and Ma TH: Tubeimoside-1 induces oxidative stress-mediated apoptosis and G0/G1 phase arrest in human prostate carcinoma cells in vitro. Acta Pharmacol Sin 37: 950-962, 2016.

46. Guerrero AD, Schmitz I, Chen M and Wang J: Promotion of caspase activation by caspase-9-mediated feedback amplification of mitochondrial damage. J Clin Cell Immunol 3: 1000126, 2012.

47. Chen M, Guerrero AD, Huang L, Shabier Z, Pan M, Tan TH and Wang J: Caspase-9-induced mitochondrial disruption through cleavage of anti-apoptotic BCL-2 family members. J Biol Chem 282: 33888-33895, 2007.

48. Nie C, Luo Y, Zhao X, Luo N, Tong A, Liu X, Yuan Z, Wang C and Wei Y: Caspase-9 mediates Puma activation in UCN-01induced apoptosis. Cell Death Dis 5: e1495, 2014.

This work is licensed under a Creative Commons Attribution-NonCommercial-NoDerivatives 4.0 International (CC BY-NC-ND 4.0) License. 